\title{
Histopathology of dairy cows' hooves with signs of naturally acquired laminitis ${ }^{1}$
}

\author{
Heloisa M.F. Mendes ${ }^{2}$, Fernando P. Casagrande ${ }^{2}$, Ingrid R. Lima ${ }^{2}$, Cairo H. Souza ${ }^{3}$, \\ Lílian D'. Gontijo ${ }^{4}$, Geraldo E.S. Alves ${ }^{5}$, Anilton C. Vasconcelos ${ }^{6}$ and Rafael R. Faleiros ${ }^{7 *}$
}

\begin{abstract}
Mendes H.M.F., Casagrande F.P., Lima I.R., Souza C.H., Gontijo L.D',, Alves G.E.S., Vasconcelos A.C. \& Faleiros R.R. 2013. Histopathology of dairy cows' hooves with signs of naturally acquired laminitis. Pesquisa Veterinária Brasileira 33(5):613-619. Departamento de Clínica e Cirurgia Veterinárias, Escola de Veterinária, Universidade Federal de Minas Gerais, Campus de Pampulha, Belo Horizonte, MG 31270-901, Brazil. E-mail: faleirosufmg@gmail.com

The purpose of this study was to investigate histological changes in dairy cows' hooves with or without injuries from naturally acquired laminitis. Cull cows with no clinical signs of hoof abnormalities (G1, n=9) and those with macroscopic lesions associated with laminitis without $(G 2, n=23)$ or with lameness $(G 3, n=7)$ were used in the study. After slaughter, samples of dermo-epidermal junctions of sole, axial and dorsal regions of the hoof were obtained and histologically processed using HE and PAS staining. Congestion, hemorrhage and inflammatory infiltrate in the dermis of sole, axial and dorsal regions were blindly and semiquantitatively evaluated by the same researcher. Inflammatory infiltrate was evaluated in the dermal laminae of axial and dorsal regions. The morphology of epidermal cells and the presence of irregularities in three regions of the basement membrane (BM) length were examined using PAS staining. Scores of lesions in different regions of the hoof in the same group and in different groups for each region of the hoof were compared using non-parametric analyses. Inflammatory infiltrate in the dermis of all regions of the hoof was detected in all groups with no significant statistical difference. Cows with no clinical signs of hoof abnormalities secondary to laminitis (G1) have inflammation scores and epidermal cell changes similar to those of groups with laminitis injuries, suggesting the existence of a prodromal phase for this disease in bovines. BM had irregularities with a variable intensity along its length, however, with no difference among groups. The pattern of BM irregularities found has not been reported so far and does not resemble the BM collapse described in horses and cattle with induced acute laminitis. Is it concluded that even in the absence of macroscopic hoof signs associated to laminitis, dairy cows have histological injuries compatible with inflammation of the dermo-epidermal junction as in affected animals. Basement membrane of cows with or without laminitis associated lesions had irregularities with an irregular distribution along its length which need to be further studied.
\end{abstract}

INDEX TERMS: Laminitis, lameness, hoove, dermo-epidermal junction, cattle.

\footnotetext{
${ }^{1}$ Received on March 4, 2013.

Accepted for publication on March 26, 2013.

${ }^{2}$ Doctoral candidate, Departamento de Clínica e Cirurgia Veterinárias, Escola de Veterinária (EV), Universidade Federal de Minas Gerais (UFMG), Av. Antônio Carlos 6627, Cx. Postal 567, Campus Pampulha da UFMG, Belo Horizonte, MG 30123-970, Brazil. E-mails: heloisafalcao@hotmail.com, passoncasagrande@hotmail.com, ingridvet@hotmail.com

${ }^{3}$ Doctoral candidate, EV-UFMG, Belo Horizonte, MG. E-mail: cairo_henrique@hotmail.com

${ }^{4}$ Veterinarian, Rua Fagundes Varela 1.791, Apto 201, Bairro São José, Divinópolis, MG 35501-283, Brazil. E-mail: liligont@gmail.com
}

\footnotetext{
${ }^{5}$ Associate Professor, Departamento de Medicina Veterinária Preventiva, Escola de Veterinária (EV), Universidade Federal de Minas Gerais (UFMG), Cx. Postal 567, Campus Pampulha da UFMG, Belo Horizonte, MG 30123970, Brazil. E-mail: geufmg@gmail.com

${ }^{6}$ Associate Professor, Departamento de Patologia Geral, Instituto de Ciências Biológicas da UFMG, Av. Antônio Carlos 6627, Belo Horizonte, MG 31270-901. E-mail: anilton@icb.ufmg.br

${ }^{7}$ Full Professor, Departamento de Medicina Veterinária Preventiva, EV-UFMG, Avenida Antônio Carlos, 6627, Caixa Postal 567, Belo Horizonte, MG 30123-970, Brazil. Research fellow of CNPq. *Corresponding author: faleirosufmg@gmail.com
} 
RESUMO.- [Histopatologia do casco de vacas de aptidão leiteira com e sem sinais de laminite naturalmente adquirida.] 0 objetivo deste trabalho foi investigar as alterações histológicas no casco de vacas leiteiras sem e com lesões de laminite, naturalmente, adquirida. Utilizaram-se animais de descarte sem lesões macroscópicas no casco (G1 n=9) e com lesões macroscópicas associadas à laminite sem (G2 n=23), ou com claudicação (G3 n=7). Após o abate, amostras da junção derme-epiderme das regiões solear, axial e dorsal do casco foram obtidas e processadas, histologicamente, nas colorações de HE e PAS. Avaliou-se, semiquantitativamente, às cegas e por um mesmo pesquisador, congestão, hemorragia e infiltrado inflamatório na derme das regiões solear, axial e dorsal. Avaliou-se infiltrado inflamatório na lâmina dermal das regiões axial e dorsal. A morfologia das células epidermais e a presença de irregularidades em três regiões do comprimento da membrana basal (MB) foram examinadas na coloração de PAS. Os escores das lesões nas diferentes regiões do casco no mesmo grupo e nos diferentes grupos para cada região do casco foram comparados através de análises não paramétricas $(\mathrm{P}<0,05)$. Infiltrado inflamatório na derme de todas as regiões do casco foi detectado em todos os grupos sem diferença estatística $(P>0,05)$. Vacas sem lesões macroscópicas secundárias à laminite (G1) apresentaram escores de inflamação e alteração de células epidermais semelhantes aos dos grupos com lesões de laminite, sugerindo a existência de fase prodrômica para a doença em bovinos. A MB apresentou irregularidades com intensidade variável ao longo de seu comprimento $(\mathrm{P}<0,05)$, porém, sem diferença entre grupos $(\mathrm{P}>0,05)$. 0 padrão de irregularidades na MB encontrado não foi relatado até o momento e não se assemelha ao colapso de MB descrito em equinos e bovinos com laminite induzida. Concluiu-se que, mesmo na ausência de lesões macroscópicas no casco causadas por laminite, vacas leiteiras apresentam lesões histológicas compatíveis com inflamação da junção derme-epiderme como em animais afetados. A membrana basal de bovinos sem e com lesões de laminite apresenta irregularidades com distribuição irregular ao longo de seu comprimento que precisam ser melhor estudadas.

TERMOS DE INDEXAÇÃO: Laminite, claudicação, casco, junção derme-epiderme, bovinos.

\section{INTRODUCTION}

Laminitis is pointed out as the cause of $62 \%$ of lameness cases in dairy cows (Nocek 1997), is highly prevalent in cows subjected to intensive (Ferreira 2003) or extensive breeding (Flor \& Tadich 2008, Silveira et al. 2009) and causes significant losses in milk production, which may reach $1.5 \mathrm{~kg}$ of milk/day (Warnick et al. 2001).

In spite of its importance, the physiopathology of laminitis remains unclear (Thoefner et al. 2005, Enemark et al. 2008). The main causal factor is believed to be ruminal acidosis caused by a high carbohydrate diet (Vermunt \& Greenough 1994, Greenough 2007, Enemark et al. 2008). Studies have shown that there is a relationship between the amount of starch in the diet and the occurrence of la- minitis (apud Enemark 2008). Thus, laminitis is currently considered a production disease, since it is related to the animals' inability to deal with metabolic demands of a high production (Mulligan \& Doherty 2008). It is worth mentioning that in addition to the nutritional factor, environmental conditions play a fundamental role in triggering laminitis (Mülling 2010).

During ruminal acidosis, the death of gram-negative bacteria takes place and consequently induces endotoxin (lipopolyssacharidae - LPS) release in rumen. These endotoxins are absorbed in the ruminal wall, reach the hepatic circulation and then the systemic bloodstream, where several inflammatory effects are triggered such as the activation of cytokines and acute-phase protein release, thrombocytopenia, leukopenia followed by leukocytosis, among others (Andersen 2003). These changes would lead to circulatory changes in the digit causing a decrease in nutrient and oxygen intake for the epidermis of the hoof. Thus, proliferation and differentiation phases of epidermal cells would be affected resulting in the formation of a soft stratum corneum with a low quality (Shearer 2006).

The liver plays a role in the detoxification of endotoxins before they get to the bloodstream, but it is believed that some damage in its function strongly impairs LPS blockade allowing them to get to the systemic circulation (Andersen 2003).

In experimental conditions, acute ruminal acidosis induced an acute inflammatory response in cattle (Gozho et al. 2005), but in natural conditions this response was not seen (Canizzo et al. 2012). On the other hand, the administration of LPS to cattle has not induced laminitis (Andersen 2003). Thus, the relationship among ruminal acidosis, inflammatory response and consequently its effect on laminitis require further investigations.

In horses, several studies have shown the importance of inflammatory events in the physiopathology of laminitis (Belknap et al. 2009, Faleiros et al. 2009, 2011a, 2011b). Findings from these studies suggest that laminitis may occur as part of the systemic inflammatory response syndrome (SIRS), which probably starts by pathogen associated molecular patterns (PAMPs) absorbed from intestine subjected to soluble carbohydrate overload (Belknap 2009).

Cattle with laminitis induced by oligofructose developed histological changes similar to those of horses with laminitis, such as inflammation, changes in epidermal cells and in the basement membrane of the hoof, among others (Thoefner et al. 2005, Danscher et al. 2010). However, it is not known which changes occur in naturally affected animals under real breeding conditions. Animals with signs of naturally acquired laminitis are thought to have histological changes similar to those of induced laminitis. The purpose of this study was to detect and compare histological injuries in the dermo-epidermal junction of sole, axial and dorsal regions of the hoof of culling dairy cows with and without clinical signs of naturally acquired laminitis.

\section{MATERIALS AND METHODS}

Animals and experimental design. Thirty-nine Girolando dairy cows from the same herd were used. These animals were 
confined in the same feedlot for 10 to 12 weeks and were selected for slaughter based on a culling annual rate of 10 percent. The main reasons for slaughter were mastitis, reproductive problems, hoof changes and age.

During their productive phase, the mean production varied from 12.3 to 14.6 liters/day/animal and cows were fed with hay and corn silage. Milking was mechanical and both the waitingand milking-rooms had concrete floor. A formaldehyde foot bath was applied with a variable frequency depending on the time of the year and the onset of injuries to the hoof. A preventive trimming was not routinely practiced on the farm. In the feedlot, each animal was fed with $13 \mathrm{~kg}$ of corn silage, $10 \mathrm{~kg}$ of sugar cane, $4 \mathrm{~kg}$ of commercial feed with $20 \%$ of protein and $800 \mathrm{~g}$ of cottonseed. The forage: concentrate ratio was 83:17.

Based on a clinical examination performed 15 to 40 days before slaughter, animals were divided in three groups. Group G1 (animals without lameness and without injuries secondary to laminitis in the hoof, n=9), G2 (without lameness and with injuries associated with laminitis, $n=23$ ) and G3 (with lameness and with injuries associated with laminitis, $n=7$ ).

Clinical evaluation. The degree of lameness was classified by the same researcher in a scale of 1 to 5 degrees as suggested by Sprecher et al. (1997). To examine the hooves, injuries associated with laminitis were considered as those described in Table 1.

\section{Table 1. Macroscopic injuries associated with laminitis (Nocek 1997, Mülling 2002, Ferreira 2003, Nicoletti 2004,Greenough 2007)}

\begin{tabular}{ll}
\hline 01- Sole hemorrhage & 10-Sole abscesso \\
02- White line hemorrhage & 11- Heel abscess \\
03- Hemorrhage on the hoof wall & 12 - White line abscess \\
04- Heel hemorrhage & 13- Soft yellow sole \\
05- Sole ulcers & 14- Double sole \\
06- Toe ulcers & 15- Sand cracks \\
07- White line widening & 16-Cork screw claw \\
08- White line fissures & 17- Stress lines on the hoof (horizontal \\
09- White line disease & lines)
\end{tabular}

At the time of slaughter, transverse hoof sections of each animal were obtained from sole, axial and dorsal regions. Fragments were cut out until the dermo-epidermal junction was reached and in accordance with what was described by Mendes (2010). Briefly, hoof pliers were used to remove the excess of stratum corneum and then a high profile disposable microtome blade was introduced in the direction of the stratum corneum for the dermis until it reached the dermo-epidermal junction in each region of the hoof to be examined.

Histology. Samples were fixed in $4 \%$ buffered formaldehyde for 48 hours, dehydrated in rising concentrations of ethyl alcohol, immersed in xylol and included in paraffin. Sections of $5 \mu \mathrm{m}$ were obtained and stained with hematoxylin and eosin (HE) and periodic-acid Schiff (PAS). HE staining was used to evaluate cells and tissue structure and PAS allowed evaluation of the basement membrane of the epidermal laminae. The same researcher blindly performed a histological analysis using an optical microscope, magnification 10x. In HE staining, scores were graded for findings related to congestion, hemorrhage and inflammatory infiltrate in the dermis of sole, axial and dorsal regions. In addition, inflammatory infiltrate was analyzed in the dermal laminae of axial and dorsal regions. Scores were graded from 0 to 4 (0-absent, 1-discrete, 2-light, 3-moderate, 4- marked) for each region examined.

The morphology of epidermal cells and the integrity of basement membrane in axial and dorsal regions of the hoof were evaluated using PAS staining. Epidermal cells were examined in the medium third of laminae. Scores were graded from 0 to $3(0$ - pre- dominance of epidermal cells with an oval nucleus perpendicular to the basement membrane, 1 - presence of about $50 \%$ of epidermal cells with oval nuclei perpendicular to the basement membrane and $50 \%$ with round nuclei, 2 - predominance of epidermal cells with round nuclei, 3- predominance of epidermal cells with elongated and flat nuclei or the absence of nuclei).

Basement membrane (BM) was examined throughout its length in three regions. Scores were graded from 0 to 4 (0-absent, 1- discrete, 2- light, 3- moderate, 4- marked) according to the intensity of the irregularities. For BM evaluation purpose in the laminar regions (dorsal and axial), the length of the epidermal laminae was divided three equal parts from the hoof capsule towards the distal phalanx (basal, medium and apical thirds).

Statistical analysis. For the comparison among groups, semi-quantitative variables were considered for each region (sole, axial and dorsal) and were compared using the Kruskal-Wallis test. Regions of each group were compared using the Friedman test. Both analyses were followed by the Dunn test. For all tests, the significance level was considered as $\mathrm{P}<0.05$.

Ethics Committee. This research has been approved by the Ethics Committee on Animal Research of Universidade Federal de Minas Gerais/Brazil (CETEA/UFMG), protocol number 033/2009.

\section{RESULTS}

\section{Lesions among groups - HE}

There were no differences as for congestion and inflammatory infiltrate in the sole dermis and in the dorsal dermis among groups, however, hemorrhage in both cases was significantly greater in $\mathrm{G} 3(\mathrm{P}<0.05)$ (Fig.1). In the axial dermis, no differences were seen as for congestion, hemorrhage and inflammatory infiltrate among groups $(\mathrm{P}>0.05)$.

Investigated lesions were found in all hoof regions, except for hemorrhage which was not detected in the axial region. The inflammatory infiltrate was particularly found in the dermis of all regions from all groups evaluated. Group
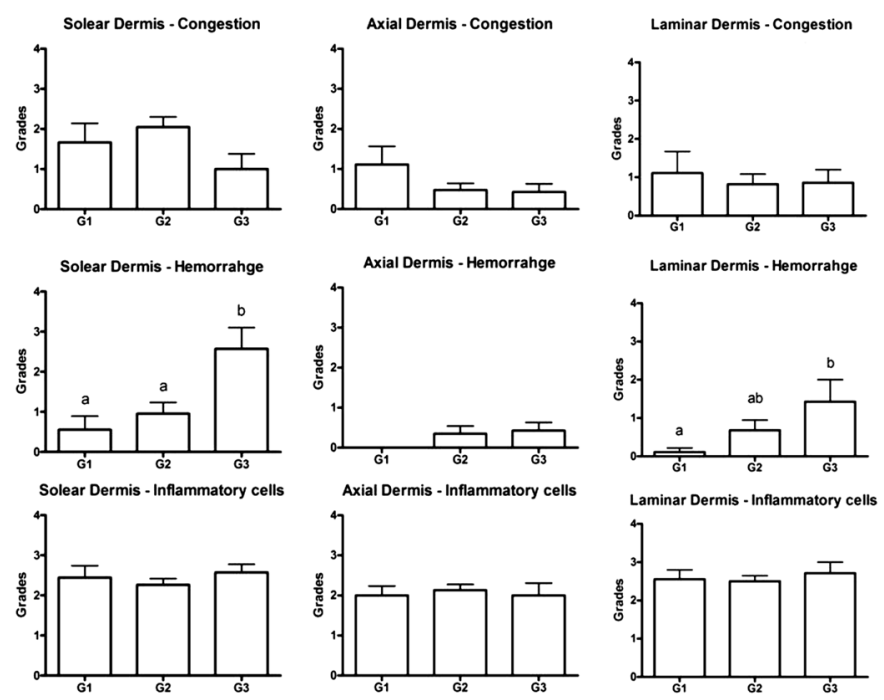

Fig.1. Comparison among groups. Scores for histological injuries (congestion, hemorrhage and inflammatory infiltrate) to the dermis of sole, axial and dorsal regions of dairy cows' hooves from groups G1, G2 and G3. Comparison of the same hoof region among groups. Means followed by similar letters do not differ statistically among each other $(\mathrm{P}>0.05)$. Means followed by different letters differ among each other $(\mathrm{P}<0.05)$. Mean \pm standard deviation. 
G1 has not differed as for the score of inflammatory infiltrate when compared to groups G2 and G3 in the hoof regions examined (Fig.1 and Fig.2).

\section{Lesions among hoof regions - HE}

When comparing within groups among different hoof regions, no difference was found in G1 as for congestion, hemorrhage and inflammatory infiltrate $(P>0.05)$. In G2, congestion was greater in the sole dermis $(\mathrm{P}<0.05)$ and there was no difference as for hemorrhage and inflammatory infiltrate. In G3, hemorrhage was greater in the sole dermis $(\mathrm{P}<0.05)$ and there was no difference as for congestion and inflammatory infiltrate (Fig.3).

As for the presence of inflammatory infiltrate in the dermal laminae, although it is present in axial and dorsal regions, no difference was seen neither among groups nor among the regions studied ( $\mathrm{P}>0.05)$ (graphs not shown).

\section{Epidermal cells and basement membrane}

There was no statistical difference $(P>0.05)$ for morphological changes in epidermal cells among groups in the same region, not even among regions within the same group. As for BM, no differences were found regarding irregularities found among groups both in the axial and in the dorsal regions in any of the three regions studied $(\mathrm{P}>0.05)$ (graphs not shown).

When comparing different regions of BM (basal, medium and apical thirds) within groups, irregularities on the basal third were found to be more pronounced in the axial region in $\mathrm{G} 1$ than on the medium third $(\mathrm{P}<0.05)$. In the dorsal region, even with no statistical difference, irre-

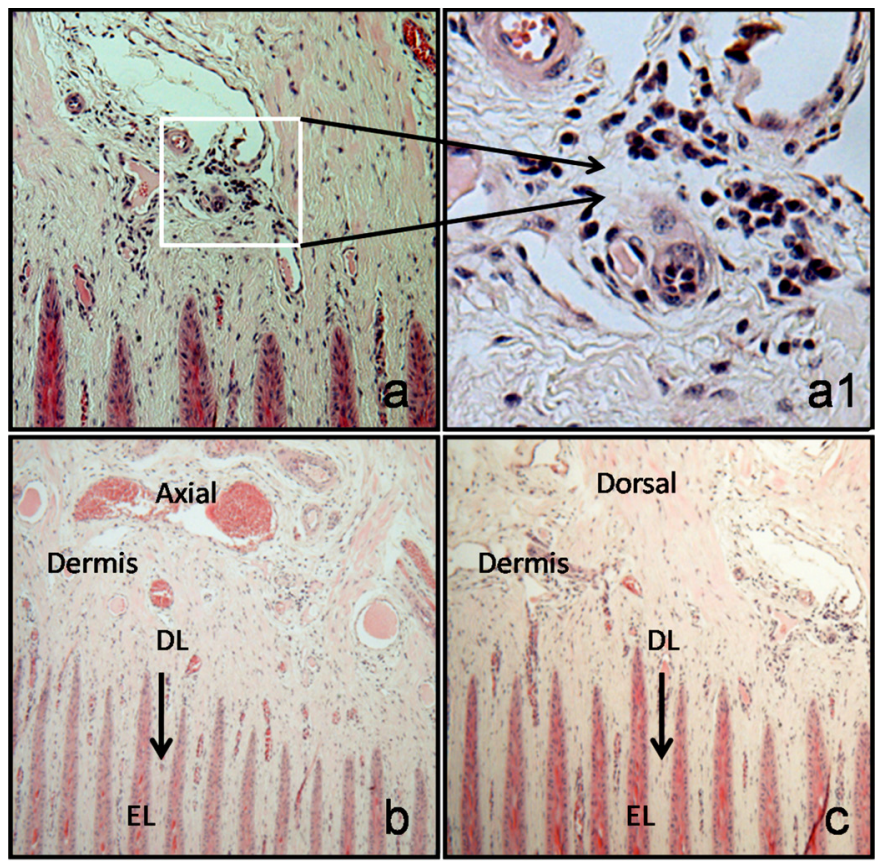

Fig.2. Histology of the dermo-epidermal junction of dairy cows' hooves. a and a1) dermal inflammatory infiltrate in the dorsal region in a cow from group G1; b and c) dermo-epidermal junction in axial and dorsal regions, respectively. DL- dermal laminae (arrow), EL- epidermal laminae.20x and 10x magnification. Hematoxylin and Eosin (HE).
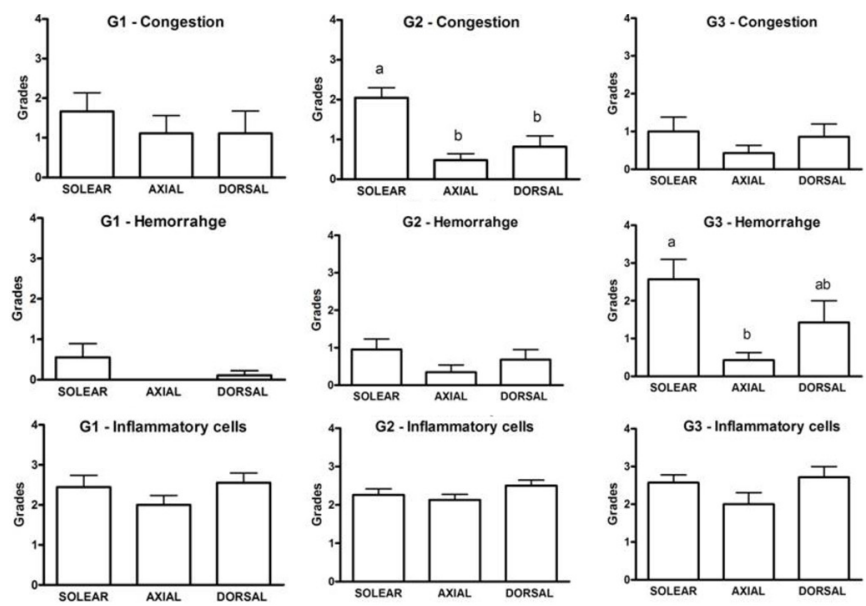

Fig.3. Comparing regions. Scores for histological injuries (congestion, hemorrhage and inflammatory infiltrate) in sole, axial and dorsal dermis of dairy cows of groups G1, G2 and G3. Comparing hoof regions among hoof regions of the same group. Means followed by similar letters do not differ statistically among each other $(\mathrm{P}>0.05)$. Means followed by different letters differ among each other $(\mathrm{P}<0.05)$. Mean \pm standard deviation.

gularities were more pronounced on the basal third than on the medium and apical thirds. In G2, irregularities were more pronounced on the basal third both in the axial and in dorsal regions $(\mathrm{P}<0.05)$. In $\mathrm{G} 3$, irregularities were more pronounced on the basal third $(\mathrm{P}<0.05)$ both in the axial and in the dorsal regions. Thus, irregularities were more pronounced on the basal third of both regions (axial and dorsal) in all groups studied (Fig.4 and Fig.5).

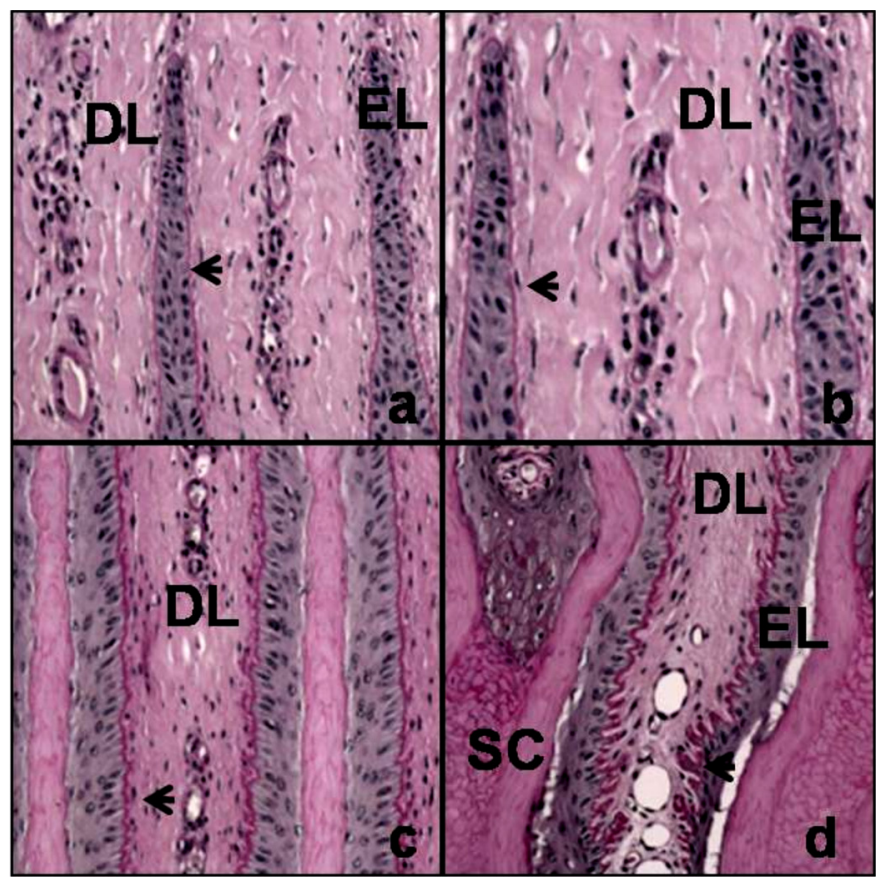

Fig.4. Histology of the dermo-epidermal junction of the dorsal region. DL- dermal lamina, EL- epidermal lamina, SC- stratum corneum, Arrow- basement membrane with variable intensity in the irregularities: $a$ and b (apical third), c (medium third), d (basal third) 20x magnification. Periodic acid Schiff (PAS). 

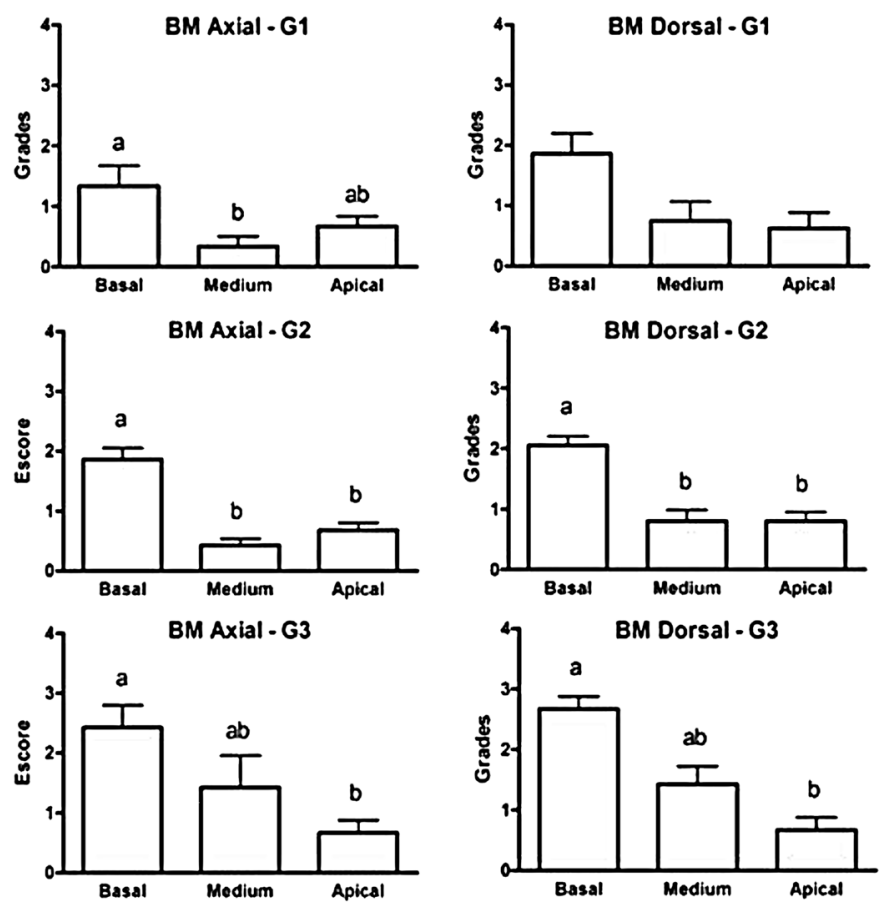

Fig.5. Graphic results of the survey on irregularities of the basement membrane (BM) in its basal, medium and apical thirds of axial and dorsal regions of dairy cows' hooves classified as in groups 1 (G1), 2 (G2) and 3 (G3). Graphs to the left allow us to compare BM regions within the same group in the axial region of the hoof. Graphs to the right allow us to compare BM regions within the same group in the dorsal region of the hoof.

\section{DISCUSSION}

In the present study, infiltrating leukocytes were found in the dermis of all cows (G1, G2 and G3), and 89\% of them had a score which was equal or higher to two (from 0 to 4). These findings are in contrast with those in the literature, when leukocyte infiltration was found in a much lower intensity. In a study, $44 \%$ of normal individuals have leukocytes within vessels and only two per cent of cells infiltrate the tissue. But, in $48 \%$ of animals with induced laminitis, leukocytes were within vessels and in $10 \%$, they were infiltrated in the dorsal region of the hoof (Thoefner et al. 2005). In another study, animals with induced laminitis did not have a significant leukocyte infiltration; however, they experienced pain and a positive response to the hoof tester, indicating that inflammatory mediators may play a role even with no evidence of leukocyte infiltration (Danscher et al. 2010).

Interestingly, even animals with no hoof injuries (G1) have inflammatory infiltrate and congestion in the same intensity observed in animals with injuries (G2 and G3). Other studies have found histological lesions in absence of clinical sings. During the peripartum period, cows kept in intensive breeding conditions underwent a modification in the collagen expression and deviation of the keratinized axis of epidermal laminae in the absence of an injury to the hoof. These histological changes are thought to be the cause and not the consequence of diseases of the corneum tissue of the hoof (Tarlton et al. 2002). Thus, ours and others' results suggest the presence of a prodromal phase for lamini- tis in cattle similar to that of horses, when animals develop the disease with no evidence of clinical signs (Pollitt 2007).

In this work, an experimental design (groups G1, G2 and G3) has been proposed in order to approach the reality found in dairy herds, considering cows with and without signs of laminitis. Animals from group G1 made up the control of the herd studied, once they did not show lameness and tissue samples were collected from hoofs which did not have any lesion. However, these animals could not be considered as a healthy control group, since discrete changes (sole hemorrhage, white line hemorrhage, hemorrhage on the hoof wall, sand cracks and stress lines on the hoof) could be found in hooves others than the one from which samples were collected. Thus, it is important to know that even animals with no injuries (in hoof that samples were collected) which are characteristic of laminitis have hoof histological changes indicative of this disease.

In horses, macrophages and lymphocytes have been detected in laminar tissues of animals without laminitis, however, an increase of monocytes occurred in animals with induced laminitis. These findings have shown a potential role of the macrophages in complex tissue changes of equine laminitis (Faleiros et al. 2011a). In cattle, similarly as the findings in horses, lymphocyte infiltration was found in the sole dermis of animals with no clinical injuries to the hoof, however, in a low score in a scale of 1 to 3 (Nilsson 1963). Thus, we may conclude that animals without clinical injuries in this study (G1) and kept under real breeding conditions, have leukocyte infiltration in the dermo-epidermal junction compatible with a more pronounced inflammatory condition than normal animals examined in other studies (Nilsson 1963, Thoefner et al. 2005, Mills et al. 2008, Danscher et al. 2010). Therefore, cellular immunity is found to play a role in the physiopathology of injuries associated with naturally acquired laminitis.

Similar to other studies (Nilsson 1963, Thoefner et al. 2005, Danscher et al. 2010), basic histological staining techniques were used to evaluate the tissue. Further studies using immunohistochemistry cell markers would be beneficial in order to classify cells in inflammatory infiltrate. In the present study, dermal hemorrhage was a constant finding in all groups, but more pronounced in G3. Changes on the dermo-epidermal junction, such as hyperemia, hemorrhage, inflammatory cells of the dermis, morphological changes in basal cells, changes in the basal membrane among others were diagnosed in cattle with induced (Thoefner et al. 2005) or naturally acquired laminitis (Nilsson 1963). Also, such as hemorrhage, congestion, thrombosis, atherosclerosis and leukocyte infiltration have not been found in dorsal, coronary, sole and bulbar regions of normal cow hooves (Mills et al.2009a), but occurred in animals with sole ulcer (Mills et al. 2009b). Sole ulcer is typical injury secondary to laminitis and occurs when the production of the corneum tissue is damaged (Lischer \& Ossent2002). Cows with sole ulcers were seen to have histological changes which are characteristic of the healing inflammatory phase. In addition, these changes occur simultaneously with the increased expression of interleukins, decreased KGF expression (keratinocyte growth factor) and increased 
KGFR expression (KGF receptor) (Mills et al. 2009b). Thus, the importance of inflammatory processes to injuries associated with laminitis is shown even due to its possible influence on the process of hoof keratinization.

Emphasizing the importance of the dermis, biomechanical tests in the hooves of animals with induced laminitis have shown that when subjected to strain, the most common location of separation was the dermis (Danscher et al. 2010). The dermis is responsible for providing the nutrients which are required for the epidermal keratinization process. In the absence of an appropriate blood supply, a low quality corneum tissue is formed increasing the susceptibility of the animal to chemical, physical or biological damages to the environment (Tomlinson et al. 2004). In addition, dermal fibroblasts play a modulating role in the keratinocyte growth. An in vitro study has shown that keratinocyte growth in hooves depends on fibroblasts, i.e., in its absence the keratinocyte does not grow (Mills et al. 2009a). Thus, dermal injuries observed in natural conditions in this study, such as congestion, hemorrhage and inflammatory infiltrate may have affected the interaction between fibroblasts and keratinocytes and changed the homeostasis of the hoof epidermis resulting in macroscopic injuries associated with laminitis.

The group of injuries involving the corneum tissue of the hoof has been known as claw horn disruption (CHD) (Hoblet \& Weiss 2001) with sole and white line hemorrhages being considered as changes which precede the formation of CHD (Clarkson et al. 1996). Animals from groups G2 and G3 have sole (39 and 14\%) and white line (30\% and $14 \%)$ hemorrhages. Increased congestion and hemorrhage, which are seen histologically, are said to precede clinical changes as proposed by Clarkson et al. (1996).

In this study, the axial region was also shown to play a role in histological injuries. Not only the sole, but coronary, sole and bulbar regions are affected in animals with sole ulcers (Mills et al. 2009b), but there are no reports on histopathology of the axial region. Changes in the axial region were discrete, except for the inflammatory infiltrate, possibly indicating that this region is less required and less exposed than the others. This is in accordance with findings from Hinterhofer et al. (2007) that showed that the hoof elasticity in this region is more preserved in animals with chronic laminitis when compared to the dorsal region of the hoof. This characteristic should be associated with strength distribution, since axial and dorsal regions are histologically similar (Fig.2).

As for the inflammatory infiltrate in dermal laminae, no difference was seen between axial and dorsal regions. It is worth considering the difficulty to differ inflammatory and endothelial cells in this location of the tissue. In horses with the use of more specific techniques (immunohistochemistry), recent studies have shown the infiltration of neutrophils and macrophages in the primary dermal laminae of animals with induced laminitis (Faleiros et al. 2009, 2011a) suggesting the importance of these cells in laminar changes. The use of more specific techniques may contribute to elucidate this characteristic in bovines.

As for the morphology of epidermal cells, there was no difference among groups regarding the same hoof re- gion, not even among hoof regions within the same group ( $P>0.05$ ) (graphs not shown). Rounding of epidermal cells takes place in animals with induced laminitis (Thoefner et al. 2005, Danscher et al. 2010), suggesting changes in the physiology of keratinocytes. In horses, apoptosis of keratinocytes has been considered an important event in physiopathology of induced laminitis (Faleiros et al. 2004). In this study, a score medium 1 was given to the morphology of epidermal cells in axial and dorsal regions, showing the beginning of the change in the morphology of keratinocytes. Thus, it is important to study biochemical and molecular characteristics of these cells as well as their behavior towards attacks.

As for the presence of BM irregularities, there were no differences among groups in any region evaluated $(P>0.05)$. An important histological change in laminitis is basement membrane stretching (Thoefner et al. 2005, Danscher et al. 2010). No differences were observed in this study regarding this change, however, while comparing BM regions in the same hoof region and in the same group, irregularities were shown to be more pronounced in the basal third than medium and apical thirds in all hoof regions and in all groups, with or without statistical difference (Fig.5).

During the histological evaluation, the presence of irregularities was seen along the BM length which does not correspond to descriptions in the literature of BM collapse in cattle with induced laminitis (Thoefner 2005, Danscher et al. 2010) and in horses (Pollitt 2007). Irregularities observed in this work are invaginations followed by BM evaginations mainly in the basal third and not as a stretching or collapse as they have already been described. They seem to follow the differentiation and keratinization processes of epidermal cells. On the epidermis of bovine soles, BM was discontinued and its thinning occurred in animals with sole ulcers (Hendry et al. 2003), suggesting that BM changes in injuries caused by laminitis. However, this discontinuity is not similar to the irregularities observed in this study. For these reasons, the scores established for BM study were defined arbitrarily based only in the irregularities distribution detected in this study. Similarly, the scores for congestion, hemorrhage, inflammatory infiltrate and morphology of epidermal cells were established arbitrarily because it wasn't possible found a similar study.

It was not possible to correlate these irregularities in the BM with the other histological changes found, thus, it was not possible to recognize the importance of this finding in the physiopathology of the changes in the hoof. This indicates the need for further studies on changes in the bovine basement membrane naturally affected by injuries associated with laminitis.

\section{CONCLUSION}

Dairy cows may have dermal inflammation and changes in epidermal cells from the sole, axial and dorsal regions of the hoof even in the absence of any macroscopic signs of laminitis. The basement membrane of cows with and without macroscopic lesions of the hoof associated with laminitis had irregularities along its length characterized by invaginations followed by evaginations which does not cor- 
respond to the changes in the basement membrane which have been described as laminitis so far. Further studies are necessary to elucidate the role that inflammatory events and morphological changes in the basement membrane play on bovine laminitis.

Acknowledgments.- To CNPq, CAPES and FAPEMIG for financial support, and to Professor Paulo Marcos Ferreira, from Escola de Veterinária da UFMG, for help us in the understanding of the macroscopic lesions on the cattle hooves.

\section{REFERENCES}

Andersen P.H. 2003. Bovine endotoxicosis: some aspects of relevance to production diseases: a review. Acta Vet. Scand. 98(Suppl.):141-155.

Belknap J.K., Moore J.N. \& Crouser E.C. 2009. Sepsis from human organ failure to dorsal failure. Vet. Immunol. Immunopathol. 129:155-157.

Canizzo C., Gianesella M., Giudice E., Messina V., Piccione G. \& Morgante M. 2012. Serum acute phase proteins in cows with SARA (Subacute Ruminal Acidosis) suspect. Arq. Bras. Med. Vet. Zootec. 64:15-22.

Clarkson M.J., Downham D.Y., Faull W.B., Hughes J.W., Manson F.J., Merritt J.B., Murray R.D., Russell W.B., Sutherst J.E. \& Ward W.R. 1996. Incidence and prevalence of lameness in dairy cattle. Vet. Rec. 138:563-567.

Danscher A.M., Toelboell T.H. \& Wattle O. 2010. Biomechanics and histology of bovine claw suspensory tissue in early acute laminitis. J. Dairy Sci. 93:53-62.

Enemark J.M.D. 2008. The monitoring, prevention and treatment of sub-acute ruminal acidosis (SARA): a review. Vet. Journal 176:32-43. (Apud Svensson \& Bergsten 1997)

Faleiros R.R., Stokes A.M., Eades S.C., Kim D.Y., Paulsen D.B. \& Moore R.M. 2004. Assessment of apoptosis in epidermal lamellar cells in clinically normal horses and those with laminitis. Am. J. Vet. Res. 65:578-585.

Faleiros R.R., Nuovo G.J. \& Belknap J.K. 2009. Calprotectin in myeloid and epithelial cells of laminae from horses with Black Walnut extract-induced laminitis. J. Vet. Intern. Med. 23:174-181.

Faleiros R.R., Nuovo G.J., Flechtner A.D. \& Belknap J.K.. 2011a. Presence of mononuclear cells in normal and affected laminae from the Black walnut extract model of laminitis. Equine Vet. J. 43:45-53.

Faleiros R.R., Leise B.S., Watts M., Johnson P.J., Black S.J. \& Belknap J.K. 2011b. Laminar chemokine mRNA concentrations in horses with carbohydrate overload-induced laminitis. Vet. Immunol. Immunopathol. 144:45-51.

Ferreira P.M., Leite R.C., Carvalho A.U., Facury Filho E.J., Souza R.C. \& Ferreira M.G. 2004. Custo e resultados do tratamento de sequelas de laminite bovina: relato de 112 vacas em lactação no sistema free-stall. Arq. Bras. Med. Vet. Zootec. 56:589-594.

Ferreira P.M. 2003. Enfermidades podais em rebanho leiteiro confinado. Tese de Doutorado, Escola de Veterinária, Universidade Federal de Minas Gerais, Belo Horizonte, MG. 79p.

Flor E. \& Tadich N. 2008. Claudicaciones en vacas de rebaños lecheros grandes y pequeños del sur de Chile. Arch. Med. Vet. 40:125-134.

Gozho G.N., Plaizier J.C., Krause D.O., Kennedy A.D. \& Wittenberg K.M. 2005. Subacute ruminal acidosis induces ruminal lipopolysaccharide endotoxin release and triggers an inflammatory response. J. Dairy Sci. 88:1399-1403.

Greenough P.R. 2007. The laminitis syndrome, p.36-54. In: Ibid. (Ed.), Bovine Laminitis and Lameness: a hands-on approach. Elsevier, Toronto, Canada.

Hendry K.A., Knight C.H., Galbraith H. \& Wilde C.J. 2003. Basement membrane integrity and keratinization in healthy and ulcerated bovine hoof tissue. J. Dairy Res. 70:19-27.

Hinterhofer C., Apprich V., Ferguson J.C. \& Stanek C. 2007. Modulus of elas- ticity and dry-matter content of bovine claw horn affected by the changes of chronic laminitis. Vet. Journal 174:605-609.

Hoblet K.H. \& Weiss W. 2001. Metabolic hoof horn disease: claw horn disruption. Vet. Clin. North Am., Food Anim. Pract. 17:111-127.

Lischer C.J. \& Ossent P. 2002. Pathogenesis of sole lesions attributed to laminitis in cattle. Proc. $12^{\text {th }}$ International Symposium on Lameness in Ruminants, Orlando, FL, p.82-89.

Mendes H.M.F. 2010. Lesões na junção derme-epiderme do casco de vacas de aptidão leiteira de descarte com e sem sinais clínicos de laminite. Dissertação de Mestrado em Medicina e Cirurgia Veterinárias, Escola de Veterinária, Universidade Federal de Minas Gerais, Belo Horizonte, MG, 74p. Disponível em <http://hdl.handle.net/1843/BUOS-8SDM87> Accessed on Feb. 27, 2013.

Mills J.A., Zarlenga D.S. \& Dyer R.M. 2009a. Bovine coronary region keratinocyte colony formation is supported by epidermal-dermal interactions. J. Dairy Sci. 92:1913-1923.

Mills J.A., Zarlenga D.S., Habecker P.L. \& Dyer R.M. 2009b. Age, segment, and horn diseases affect expression of cytokines, growth factors, and receptors in the epidermis and dermis of the bovine claw. J. Dairy Sci. 92:5977-5987.

Mulligan F.J. \& Doherty M.L. 2008. Production diseases of the transition cow. Vet. Journal 176:3-9.

Mülling C.K.W. 2002. Theories on the pathogenesis of white line disease: an anatomical perspective. Proc. $12^{\text {th }}$ International Symposium on Lameness in Ruminants, Orlando, FL, p.90-98.

Mülling C.K. 2010. A decade of progress and problems in understanding lameness in dairy cows and its welfare implications. Proc. $26^{\text {th }}$ World Buiatrics Congress, Santiago, Chile, p.37-49.

Nicoletti J.L.M. 2004. Manual de Podologia Bovina. Manole, Barueri. 126p.

Nilsson S.A. 1963. Clinical, morphological, and experimental studies of laminitis in cattle. Acta Vet. Scand. 1(Suppl.):1-304.

Nocek J.E. 1997. Bovine acidosis: implications on laminitis. J. Dairy Sci. 80:1005-1028.

Pollitt C.C. 1999. Equine Laminitis: a revised pathophysiology. Proc. $45^{\text {th }}$ Annual Convention of the American Association of Equine Pathology, p.188-192.

Svenson C. \& Bergsten C. 1997. Laminitis in young dairy calves fed a high starch diet and with a history of bovine viral diarrhea virus infection. Vet. Rec. 140:574-577.

Shearer J.K. 2006. The transition period and lameness due to claw disorders in dairy cows. Proc. North American Veterinary Conference, Orlando, FL, p.47-48.

Silveira J.A.S., Albernaz T.T., Oliveira C.M.C., Duarte M.D. \& Barbosa J.D. 2009. Afecções podais em vacas da bacia leiteira de Rondon do Pará. Pesq. Vet. Bras. 29:905-909.

Sprecher D.J., Hostetler D.E. \& Kaneene J.B. 1997. A lameness scoring system that uses posture and gait to predict dairy cattle reproductive performance. Theriogenology 47(6):1179-1187.

Tarlton J.F., Holah D.E., Evans K.M., Jones S., Pearson G.R. \& Webster J.F. 2002. Biomechanics and Histopathological changes in the support structures of bovine hooves around the time of first calving. Vet. Journal 163:196-204.

Thoefner M.B., Wattle O., Pollitt C.C., French K.R. \& Nielsen S.S. 2005. Histopathology of oligofructose-induced acute laminitis in heifers. J. Dairy Sci. 88:2774-2782.

Tomlinson D.J., Mülling C.H. \& Fakler T.M. 2004. Formation of keratins in the bovine claw: roles of hormones, minerals, and vitamins in functional claw integrity: an invited review. J. Dairy Sci. 87:797-809.

Vermunt J.J. \& Greenough P.R. 1994. Predisposing factors of laminitis in cattle. Brit. Vet. J. 150:151-164.

Warnick L.D., Janssen D., Guard C.L. \& Gröhn Y.T. 2001. The effect of lameness on milk production in dairy cows. J. Dairy Sci. 84:1988-1997. 